\title{
O Purgatório e a salvação da alma na Braga de setecentos
}

\author{
The Purgatory and the salvation of the soul in Braga in the 18th \\ century.
}

\section{RESUMO}

Neste artigo é nosso objetivo demonstrar os mecanismos espirituais utilizados pelos católicos bracarenses no século XVIII, em busca da salvação de sua alma no além, evitando a condenação eterna do Inferno e o rápido resgate dos castigos do Purgatório. O estudo documental das confrarias das Almas de Braga possibilitou avaliar de que forma estas instituições celebravam missas pelas almas de todos sem distinção. A análise de 250 testamentos bracarenses setecentistas revelou os serviços espirituais determinados pelos fiéis, que fossem celebrados durante o período de velório e após o enterro, de forma não perpétua. Já uma avaliação de diversas fontes documentais confraternais bracarenses tornou possível o estudo dos legados pios perpétuos em favor da alma.

Palavras-chave: Escatologia católica - Purgatório - Indulgências - Sufrágios - Braga Setecentista

\section{ABSTRACT}

In this article it's our purpose to demonstrate the spiritual mechanisms used by the Catholics of Braga in the XVIII century so that could achieve the salvation of their souls, avoiding the eternal condemnation in Hell and the quick deliverance from the punishments of Purgatory. The documental study from the confraternities of Souls in Braga made possible to evaluate in which way these institutions celebrated masses for the souls of everyone without distinction. The analysis of 250 testaments from persons of Braga of the XVIII century showed the spiritual services that the faithful ordered to be celebrated during the period of the funeral and after the burial, in a non-perpetual way. Also an evaluation of various documental sources from local confraternities made possible the study of the perpetual pious legacies in favor of the soul.

Keywords: Catholic eschatology - Purgatory - Indulgences - Suffrages - Braga in 18th century

* Doutor em História Moderna pela Universidade do Minho. Membro do Lab2PT- Instituto de Ciências Sociais, Braga, Portugal. CV: Ehttp://orcid.org/0000-0001-5270-5692?lang=pt>. 


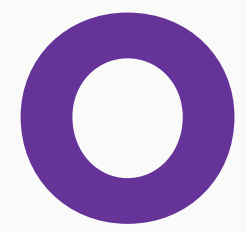

Purgatório não surgiu com o cristianismo primitivo. De fato, o termo aparece referenciado pela primeira vez, de modo claro, apenas no final do século XII, por um médico parisiense chamado Pierre le Mangeur, que propôs esta designação, posteriormente adotada pelo Papa Inocêncio III. Era ainda então uma concepção teológica mal definida, pois só a partir do século XIV, na França, é que a ideia de um Purgatório purificador das almas por intermédio do fogo se afirmou. Foi apenas a partir dos séculos XIV, XV e XVI, que se assistiu à expansão em maior escala da devoção e interiorização do Purgatório na mentalidade da sociedade cristã (Le Goff, 1993, p. 425).

O grande momento de afirmação definitiva do Purgatório enquanto lugar de acolhimento das almas dos falecidos, em pé de igualdade com o Paraíso e o Inferno, ocorre somente no século XVI, com o Concílio de Trento, que solenemente confirma e reforça a existência deste lugar de purificação, em contraponto ao Protestantismo nascente, que o negou (Abreu, 2002, p. 252). De lugar de exceção, para onde apenas iriam algumas almas necessitadas de menor purificação, o Purgatório passou a ser concebido como o destino inevitável dos fiéis que escapavam ao Inferno, verdadeira etapa normal na migração que a alma fazia após a morte, pois só havia garantia de passagem imediata ao Céu para aqueles que morressem reconhecidamente em estado de santidade pela Igreja Católica (Ariés, 1988, p. 197-198).

O Purgatório da Época Moderna era apresentado como um verdadeiro Inferno, no que dizia respeito aos tormentos, às penas e castigos infligidos aos pecadores, antes que pudessem alcançar o Paraíso, apenas com a diferença de não ser eterno. Neste sentido, os homens da Idade Moderna, para salvar sua alma do castigo eterno, deviam cumprir os preceitos religiosos, vivendo de acordo com eles, com fé e amor em Deus, para além da obrigação de amar os outros seres humanos. Por outro lado, a libertação das almas do Purgatório era obtida por meio das orações em seu favor e, sobretudo, pela celebração de missas por sua intenção, intercedendo junto de Deus para que as libertasse rapidamente desse lugar de sofrimento. Simultaneamente, os fiéis podiam obter ainda a redução futura das penas do Purgatório, pelas indulgências que as autoridades eclesiais lhes concediam, mediante certos requisitos, bem como procedendo a obras de caridade, que os ajudariam a alcançar a salvação. ${ }^{1}$

As almas esperavam poder contar com a solidariedade dos vivos para as sufragarem, pois enquanto estivessem no Purgatório pouco ou nada podiam pedir para si mesmas (Vovelle, 1974 , p. 126). Por tal razão, na Idade Moderna, em Braga, os testadores determinavam a celebração de missas e ofícios pelas suas almas, assunto a que voltaremos neste artigo. Todavia, também as instituições da Igreja, como as confrarias, se preocupavam com a assistência às almas de seus membros, prevendo a celebração de sufrágios em seu benefício. Pertencer a uma confraria era uma garantia de auxílio espiritual para depois da morte. Ora as confrarias determinavam a celebração de sufrágios pelos seus irmãos, mas só as confrarias das Almas, especificamente, mandavam celebrar missas pelo resgate de todas as almas ainda cativas neste

1 Para obter indulgências, os fiéis deviam rezar e praticar obras de caridade em dias e locais específicos (Delumeau, 1989, p. 427 e 444). 
local de punição, e não apenas pelas dos confrades que faziam parte delas. Em Braga, no século XVIII, tais irmandades estavam igualmente presentes. Não eram as instituições confraternais mais importantes da urbe. A maioria das confrarias das Almas da cidade de Braga não era poderosa financeiramente, geralmente não ultrapassando os 300 mil réis anuais de receitas, com exceção da confraria das Almas de São Vítor. ${ }^{2}$ A história da fundação destas organizações demonstra que, em Braga, elas foram criadas entre os séculos XVII e XVIII e que quando de sua fundação Braga já tinha dezenas de outras confrarias em funcionamento.

É também notório que estas confrarias conheceram inicialmente maior sucesso nas zonas limítrofes da cidade, e não no centro, onde se concentrava o funcionalismo religioso e administrativo. Provavelmente eram os bracarenses mais pobres os que maior interesse manifestavam na adesão a estas instituições, pois viam a entrada nas confrarias mais poderosas da cidade praticamente vedada, pelas altas jóias de entrada a que estavam sujeitos. O sentido comunitário das confrarias das Almas, que sufragavam todas as Almas do Purgatório em comum, era possivelmente um atrativo para os grupos sociais mais desfavorecidos. ${ }^{3}$

A caraterística que distinguia as confrarias das Almas do Purgatório era a celebração de sufrágios pelo resgate das mesmas. Uma das principais formas de arrecadação de meios financeiros para custear estas missas era por meio de peditórios semanais. Os mordomos circulavam pela cidade, transportando uma bacia, vestindo as opas e veneras ${ }^{4}$ que os identificavam como membros da confraria, pedindo aos habitantes nas ruas e nas habitações para contribuírem monetariamente para as missas pelas almas do Purgatório. ${ }^{5}$ Por esta via, os mordomos destas instituições privilegiavam uma postura de contato e de proximidade regular relativamente aos habitantes, apelando à piedade dos bracarenses lembrando-lhes a necessidade do resgate das Almas do Purgatório, em especial as de seus familiares e amigos.

2 Na localidade de Angra do Heroísmo, no Arquipélago dos Açores, as confrarias das Almas situavam-se quase no topo da escala hierárquica confraternal desta diocese. Em Braga, pelo contrário, a situação era inversa. (Enes, 1991, p. 281, 290).

3 Segundo Margarida Durães, as confrarias das Almas eram de cariz mutualista, sendo como que "instituições de refúgio piedoso e religioso para as populações mais desprotegidas neste mundo e que se atemorizavam com a sua sorte no outro"(Durães, 2000, p. 306-307).

4 As veneras eram as insígnias identificativas da irmandade colocadas nas vestes dos mordomos.

5 Como refere Cecília Figueiredo, em Minas Gerais existiam leigos, provenientes de várias confrarias, que pediam esmolas à população, envergando as suas vestes identificativas e transportando uma bacia. (Figueiredo, 2011, p. 42-43). Sobre os peditórios semanais nas confrarias das Almas bracarenses consulte-se ARQUIVO DA IGREJA DA SÉ DE BRAGA (doravante AISB), Fundo da Confraria das Almas da Sé, Estatutos da confraria das Almas sita na Sé desta cidade 1723, fls. 6, 24: ARQUIVO DA IGREJA DE SÃO LÁZARO (doravante AISL) Fundo da confraria das Almas de São João da Ponte, Estatutos da confraria das Almas de São João da Ponte, desta cidade de Braga, 1784, fl. 7v.; ARQUIVO DA IGREJA DE SÃO VICENTE (doravante AISVTE), Fundo da confraria das Almas de São Vicente, Estatutos da confraria das Almas de São Vicente, 1667, fl. 11; Estatutos reformados da confraria das benditas Almas de São Vicente, 1761, fl. 25v.; ARQUIVO DA IGREJA DE SÃO VÍTOR (doravante AISV), Fundo da irmandade das Almas de São Vítor, Livro de estatutos da confraria das Almas de São Vitor, 1738, fls. 11v.-12. Até 1776, na confraria das Almas da Sé, quem fazia esta arrecadação eram os sacadores de esmolas. Após esta data, passou o servo da confraria a ser responsável por essa incumbência, com algumas alterações: pedia todos os dias de manhã na Sé e posteriormente em outros locais "costumados". AISB, Fundo da confraria das Almas da Sé, Estatutos da confraria das almas sita na Sé desta cidade, 1723, fls. 27-27v. Na confraria das Almas de São Vicente em 1761, também o servo da confraria passou a exercer esta tarefa, até então a cargo dos mordomos. AISVTE, Fundo da confraria das Almas de São Vicente, Estatutos reformados da confraria das benditas almas de São Vicente, 1761, fl. 25. 
No entanto, esta era uma tarefa que tomava tempo e esforço aos mordomos, podendo estes recusar tal encargo, desde que pagassem certa quantia de seu próprio bolso. ${ }^{6}$ Foi o que fizeram, por exemplo, os mordomos da confraria das Almas de São Vítor, a partir da década de 1760, os quais foram progressivamente deixaram de fazer o peditório semanal, preferindo desembolsar cada um 1.200 réis anuais.? Como os mordomos nem sempre se mostravam disponíveis, as irmandades das almas de São Vítor, da Sé, de São Vicente e de São João da Ponte, determinaram, na segunda metade da centúria, que seus servos ${ }^{8}$ procedessem igualmente a peditórios em substituição daqueles membros da Mesa. ${ }^{9}$

Estas confrarias tinham outros meios de arrecadar fundos. Deste modo, colocavam caixas identificadas nas ruas da cidade, para que os devotos depositassem seus donativos. Assim, estes podiam sempre dar seu contributo para as almas do Purgatório. Outro expediente encontrado foi a entrega de mealheiros, por parte dos mesários, a pessoas devotas que deles se encarregavam durante determinado período de tempo. ${ }^{10}$ Aparentemente, algumas pessoas especialmente devotas das Almas do Purgatório solicitavam estes objetos, recebiam-nos em suas casas, para elas próprias neles colocarem esmolas, sendo possível que depois os fizessem circular por amigos e vizinhos de forma a obter mais donativos. ${ }^{11}$

Como sufragavam estas confrarias as Almas do Purgatório? A confraria das Almas da $\mathrm{Sé}^{12}$ de Braga, a princípio, estabeleceu a celebração de missas diárias ou semanais, conforme os fundos recolhidos possibilitassem. Posteriormente optou por celebrar uma missa diária, todas as manhãs, pelas Almas do Purgatório, e outra missa aos domingos e dias santos, com a mesma intenção. ${ }^{13} \mathrm{Em}$ 1781, os gestores da confraria criticaram esta prática, que aplicava todos os sufrágios pelas almas em geral, e não em particular pelos confrades e benfeitores da confraria, vivos e defuntos, o que só sucedia para as missas celebradas por ordem da irmandade, quando do falecimento de cada irmão. Decidiram então que as missas diárias e as dos dias santos e domingos fossem aplicadas pelas almas dos confrades vivos e defuntos da instituição, bem como pelas almas de todos os seus benfeitores. Só as missas celebradas por ocasião do

6 AISV, Fundo da irmandade das Almas de São Vítor, Livro de termos de mesa da irmandade das Almas de São Vítor. 1752-1776, fl. 217; Livro de termos de mesa da irmandade das Almas de São Vitor, 1776-1794, fl. 248.

7 AISV, Fundo da irmandade das Almas de São Vítor, Livro de termos de mesa da irmandade das Almas de São Vítor, 1752-1776, fls. 217, 232v.-233, 332; Livro de termos de mesa da irmandade das Almas de São Vítor, 1776 1794, fl. 293.

8 Em Braga, algumas confrarias tinham indivíduos ao seu serviço designados por servos, especialmente no apoio às celebrações litúrgicas e na limpeza da igreja e altares. Tinham funções semelhantes às de um sacristão.

9 AISL, Fundo da confraria das Almas de São João da Ponte, Livro de termos de mesa da confraria das Almas de São João da Ponte, 1757-1786, fls. 74v.-75; AISV, Fundo da irmandade das Almas de São Vítor, Livro de termos de mesa da irmandade das Almas de São Vitor, 1752-1776, fls. 302-303; Livro do recibo da irmandade das Almas de São Vítor, 1747-1786, fls. 142-145, 162-164; Livro do recibo da irmandade das Almas de São Vítor, 1786-1812, fls. 22-24, 41v.-42, 61-65. O arcebispo D. Gaspar mudou o dia do mercado semanal para a terça-feira o que pode ter tido reflexos na data em que se faziam peditórios (Abreu, 1997, p. 88).

10 A confraria das Almas do Funchal enviava mealheiros para casa de particulares, com o objetivo de angariação de esmolas (Estreia, 2002, p. 108).

11 AISB, Fundo da confraria das Almas da Sé, Estatutos da confraria das Almas sita na Sé desta cidade, 1723, fl. 41; AISL, Fundo da confraria das Almas de São João da Ponte, Estatutos da confraria das Almas de São João da Ponte, 1784, fls. 9-9v.; AISVTE, Fundo da confraria das Almas de São Vicente, Estatutos da confraria das Almas de São Vicente, 1667, fl. 11v.; AISV, Fundo da irmandade das Almas de São Vítor, Livro de estatutos da confraria das Almas de São Vitor, 1738, fl. 9v.

12 Foi fundada em 1723 pelo arcebispo D. Rodrigo de Moura Teles.

13 AISB, Fundo da confraria das Almas da Sé, Estatutos da confraria das Almas da Sé desta cidade, 1723, fls. 8, 36v.37. 
"Aniversário"14 da confraria passariam a ser aplicadas pelas Almas do Purgatório em geral.

Figura 1: Altar das Almas, Claustro da Sé de Braga

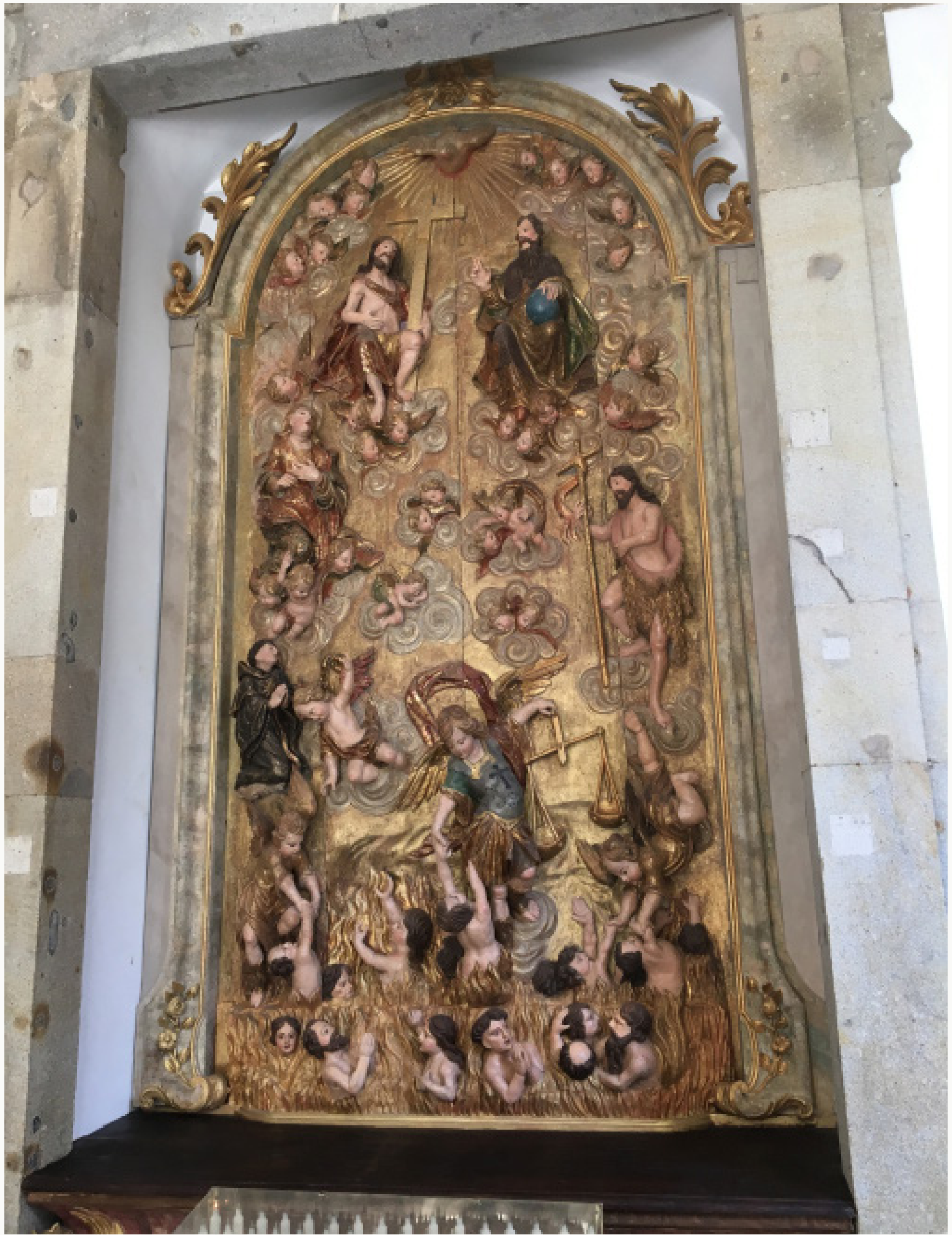

Fonte: Museu da Sé de Braga

14 aniversário era uma celebração anual presente em muitas confrarias, na qual se celebravam missas e ofícios pelos confrades vivos e defuntos. A confraria das Almas da Sé, em 1781, como vemos, determinou outra orientação. 
Com esta mudança, a confraria das Almas da Sé aproximava-se de outras confrarias da cidade, as quais celebravam missas todo o ano, para sufragar apenas as almas de seus membros vivos e defuntos, bem como as dos seus benfeitores. Mas tal prática que privilegiava somente seus membros e os que contribuiam para a associação afastava-se do objetivo inicial desta instituição, que era o resgate de todas as almas do Purgatório. Não seguia, aliás, os procedimentos de suas congéneres, que sufragavam todas as almas. Por tal razão, posteriormente, em 1794, os responsáveis da confraria denunciaram esta prática e retornaram à situação anterior. ${ }^{15}$ É possível ter ocorrido uma reação negativa por parte dos bracarenses, quando souberam que a maioria das missas celebradas servia apenas para sufrágio das almas dos membros da confraria, bem como daqueles que a apoiassem com suas ajudas financeiras.

A confraria das Almas de São João da Ponte, ${ }^{16}$ na década de 1720 celebrava uma missa semanal, nas segundas-feiras, ${ }^{17}$ pelas Almas do Purgatório, bem como uma missa todos os domingos e dias santos, embora no segundo caso, não saibamos se as Almas do Purgatório eram sufragadas. ${ }^{18}$ A partir de meados do século XVIII, a missa da segunda-feira deixou de ser celebrada, mas as missas dos domingos e dias santos, em 1784, eram celebradas tanto pelo resgate das Almas do Purgatório em geral, como também pelas almas dos confrades e benfeitores vivos e defuntos. É possível aventar que, a princípio, as missas de domingos e dias santos tenham sido apenas celebradas pelas almas dos confrades e benfeitores da instituição, e que com o fim da missa de segunda-feira se agregassem todas as intenções nas missas dos domingos e dias santos. ${ }^{19}$

Por seu turno, a confraria das Almas de São Vítor era a que mais despendia em sufrágios por todas as Almas do Purgatório. ${ }^{20}$ Na década de 1720 mandava já celebrar uma missa diária pelas almas, ao romper do dia. Nas segundas-feiras, esta missa era cantada pelos capelães da confraria e incluía, no fim, uma procissão solene em volta da igreja. ${ }^{21}$ Por volta de 1730 a confraria acrescentou uma missa às 11 horas da manhã, todos os domingos e dias santos, que também revertia em favor das Almas do Purgatório.22 Em 1745, a Mesa decidiu

15 AISB, Fundo da confraria das Almas da Sé, Estatutos da confraria das Almas da Sé desta cidade, 1723, fls. 36v.$38 \mathrm{v}$.

16 Esta confraria já existia no século XVII. Localizava-se nos arrabaldes da cidade.

17 A confraria das Almas da vila de Cabeção, no século XVIII, celebrava igualmente, nas segundas-feiras, uma missa com a mesma intenção (Beirante, 2011, p. 49).

18 AISL, Fundo da confraria das Almas de São João da Ponte, Estatutos da confraria das almas de São João da Ponte, desta cidade de Braga, 1784, fl. 10v.; Livro de registo das certidões das missas da confraria das benditas Almas de São João da Ponte, 1768-1802, fls. 1v.-85v.; Livro de termos de mesa da confraria das Almas de São João da Ponte, 1726-1757, fls. 9, 39v., 47.

19 A missa dos domingos e dias santos, em 1784, tinha lugar às seis horas da manhã no Inverno e às cinco no Verão. AISL, Fundo da confraria das Almas de São João da Ponte, Estatutos da confraria das Almas de São João da Ponte, desta cidade de Braga, 1784, fl. 10v. Em relação ao fim da missa celebrada nas segundas-feiras, é possível que a confraria se tivesse visto confrontada com a insuficiência de verbas.

20 A confraria das Almas de São Vítor foi fundada nos princípios do século XVIII com os primeiros estatutos aprovados em 1704. Localizava-se na igreja desta paróquia já nos arrabaldes da cidade.

21 AISV, Fundo da irmandade das Almas de São Vítor, Livro de estatutos da confraria das Almas de São Vítor, 1738, fl. 17: Livro de missas da irmandade das Almas de São Vitor, 1722-1738, fls. 1-3. AISV, Fundo da irmandade das Almas de São Vítor, Livro de missas da irmandade das Almas de São Vitor, 1741-1787, fls. 162v.-165. As procissões efectuadas para celebração dos defuntos serviriam, na mentalidade religiosa e popular da época para apaziguar as almas dos que tinham partido (Conceição, 1996, p. 157-159).

22 AISV, Fundo da irmandade das Almas de São Vítor, Livro de missas da irmandade das Almas de São Vitor, 1722 1738 , fl. 25v. 
acrescentar outra missa com a mesma intenção, celebrada nos domingos e dias santos, além das já existentes nesses dias. Esta missa decorria logo a seguir à primeira eucaristia celebrada diariamente. O crescimento dos sufrágios continuou na década seguinte. Em 1755, a irmandade decidiu converter as duas missas celebradas especificamente nos domingos e dias santos, numa segunda eucaristia celebrada cotidianamente, com uma diferença. Esta missa sufragava as almas dos confrades vivos e defuntos, bem como as de todos os benfeitores da instituição, o que era uma forma de, como na confraria das Almas da Sé, apelar à generosidade individual dos fiéis, para ter mais sufrágios em prol de sua salvação futura, buscando também captar novos membros para suas fileiras. ${ }^{23}$ Esta confraria, ao contrário de sua congênere da Sé, procurou manter um equilíbrio entre sufrágios por todas as almas e pelas almas de seus membros e benfeitores.

Por seu turno, a confraria das Almas de São Vicente, ${ }^{24}$ no início do século XVIII, celebrava igualmente uma missa cantada pelas almas, à segunda-feira, com uma procissão no fim. ${ }^{25}$ Durante a mesma, que não saía da igreja, o celebrante lançava água benta para aspergir as sepulturas dentro do templo. A procissão era feita pelos clérigos celebrantes, acompanhados de dez devotos das Almas. Depois desta missa solene inicial, nas segundas-feiras, a confraria das Almas de São Vicente determinava a celebração de outras missas celebradas pelas Almas do Purgatório, no mesmo dia, pagas pelos devotos no cumprimento de ajuste feito por estes com a confraria, perfazendo um total de 150 missas anuais. ${ }^{26} \mathrm{Em} 1761$ a revisão dos estatutos redefiniu os serviços pios prestados. A irmandade determinou que se celebrasse uma missa diária por todas as almas do Purgatório, ao romper da manhã, ${ }^{27}$ a exemplo das confrarias das Almas da Sé e das Almas de São Vítor. Em suma, é possível afirmar que estas confrarias tomaram como objetivo a celebração pelo menos semanal, mas frequentemente diária, das almas do Purgatório, numa assistência espiritual imprescindível para aqueles que não podiam dispender recursos financeiros com o fim de alcançar a salvação.

Deve ser realçado igualmente que, em contraste com as outras confrarias locais, as irmandades das Almas de Braga determinavam que as celebrações do seu "Aniversário" fossem em benefício das almas do Purgatório, e não apenas pelas de seus confrades vivos e defuntos e benfeitores. ${ }^{28} \mathrm{~A}$ comemoração anual destas instituições era, assim, sua ocasião favorita para,

23 AISV, Fundo da irmandade das Almas de São Vítor, Livro de termos de mesa da confraria das Almas de São Vitor, 1734-1752, fl. 103; Livro de termos de mesa da confraria das Almas de São Vitor, 1752-1776, fls. 39-39v.

24 Estava localizada na igreja da irmandade de São Vicente. Foi fundada em 1667.

25 AISVTE, Fundo da confraria das Almas de São Vicente, Estatutos da confraria das Almas de São Vicente, 1667, fls. 7-8.

26 Idem, fls. 5v.-6, 7-8, 9v.-10. Situação idêntica se verificava em Meadela, onde a missa da segunda-feira, celebrada pelas almas, era paga pelos fregueses (Solé, 2001, p. 277-278).

27 Tinha também uma missa aos domingos e dias santos pelos benfeitores e confrades vivos e defuntos, como já constatamos em outras confrarias das Almas. AISVTE, Fundo da confraria das Almas de São Vicente, Estatutos da confraria das benditas Almas de São Vicente, 1761, fl. $28 \mathrm{v}$.

28 Nas confrarias das Almas de São Vítor, São Vicente e de São João da Ponte havia igualmente todos os anos, por altura do São Miguel, um outro peditório em que toda a Mesa participava. Este peditório era efetuado nas zonas limítrofes da cidade, permitindo a recolha de algum dinheiro, mas, também e sobretudo, de géneros: linho e grão de milho. AISB, Fundo da confraria das Almas da Sé, Estatutos da confraria das Almas da Sé desta cidade, 1723, fls. 11v.-12; AISL, Fundo da confraria das Almas de São João da Ponte, Livro dos termos da confraria das Almas de São João da Ponte, 1726-1757, fls. 58v., 65, 73; Livro dos termos da confraria das Almas de São João da Ponte, 1797-1802, fl. 35; AISV, Fundo da irmandade das Almas de São Vítor, Livro de estatutos da confraria das Almas de São Vitor, 1738, fl. 9; Livro de termos de mesa da irmandade das almas de São Victor, 1794-1823, fls. 22, 24v., 38; AISVTE, Fundo da confraria das Almas de São Vicente, Estatutos da confraria das benditas Almas de São Vicente, 1761, fls. 10v.-12. 
em simultâneo, procederem à exaltação da irmandade e também sufragarem as almas de todos num sentido comunitário. Não é por isso de admirar que tivesse lugar no mês de novembro, o mês por excelência de comemoração dos defuntos. Cabe lembrar, aliás, que o dia dois desse mês estava determinado pela Igreja como aquele no qual celebrava sufrágios pelas almas de todos aqueles que já tinham partido e esperavam alcançar a sua libertação do Purgatório.29

\section{Os serviços fúnebres e os sufrágios celebrados}

Apesar das confrarias das Almas de Braga prestarem uma assistência espiritual que beneficiava as almas de todos sem distinção, os bracarenses do século XVIII tiveram a preocupação de assegurar para suas almas em particular a celebração de serviços pios que as ajudassem a alcançar a salvação. Foi por intermédio da análise de 250 testadores bracarenses setecentistas que foi possivel conhecer de forma mais aprofundada esta temática: como projetavam seu velório e o período posterior ao funeral, a nível celebrativo? ${ }^{30}$

Começando pelo período de velório, havia duas modalidades pias principais, escolhidas pelos testadores estudados, de ambos os sexos: a celebração de ofícios por diversos sacerdotes e, com maior importância, a celebração de missas de corpo presente. Assim, 82\% dos testadores analisados solicitaram a celebração de um destes serviços pios ou, até, ambos em conjunto. Deve ressalvar-se que os ofícios eram um conjunto de preces, leituras (também conhecidas por lições) e salmos que os clérigos participantes ${ }^{31}$ rezavam conjuntamente, nas diferentes horas canônicas, pedindo a Deus insistentemente que aceitasse a alma do defunto. ${ }^{32}$ Tendo em atenção a capacidade financeira de cada um, os ofícios podiam ser mais curtos ou prolongados no tempo: havia ofícios comuns de três lições e outros para os mais ricos, de nove lições. A análise testamental verificou que os ofícios eram, sobretudo, reservados para as exéquias fúnebres. Por outro lado, os testadores podiam deixar a obrigação aos clérigos de celebrarem também, cada um, uma missa pela sua alma, no local onde celebrassem o ofício. Efetivamente $6 \%$ dos testadores analisados solicitaram esta associação de duas modalidades pias, enquanto uma percentagem semelhante pediu somente a celebração de um ofício. Por seu turno, 10\% pediram, durante o período do velório até ao sepultamento, a celebração de ofícios sem que os sacerdotes neles participantes tivessem de celebrar uma missa no mesmo local, mas estipularam simultaneamente a celebração de sufrágios noutras igrejas da cidade. Outros testadores ainda determinaram a celebração de ofícios com a obrigação de os clérigos

29 É o dia de Finados ou de Fiéis Defuntos, celebrado a dois de Novembro.

30 Fonte: ARQUIVO DISTRITAL DE BRAGA (doravante ADB), Testamentos do Fundo de Provedoria; AISB, Livro de testamentos da freguesia da Sé, 1738-1785, fls. 10-10v., 12-13, 19-19v., 26v.-27v., 32-33, 35-36, 40v.-41, 50v.51, 67v.-68, 74-75, 85-85v., 89-89v., 111v.-112, 129-130., 134v.-135, 135, 147-148, 160-161, 165v.-166v., 175176, 189, 197v.-198; Livro de testamentos da freguesia da Sé, 1785-1814, fls. 5-5v., 37v.-38, 49v.-50, $57 \mathrm{v} .-58$

31 A análise testamental efetuada mostrou que o número de clérigos participantes nos ofícios variava entre 10 a 60 indivíduos. A tendência recaía na escolha de 10, 20 ou 30 sacerdotes.

32 O ofício de defuntos centrava-se sobretudo nas horas canónicas vésperas, matinas e laudes. (Enciclopedia de la Religion Católica, 1953, p. 963-965). 
neles participantes celebrarem uma missa no local e, simultaneamente, a realização de sufrágios que tinham lugar noutros templos, durante o período do velório. A sua percentagem foi de $8 \%$.

Todavia, a modalidade congregadora do maior número de testadores foi a dos que pediam apenas a celebração de missas de corpo presente, com uma percentagem de cerca de $52 \%$ do total de indivíduos estudados. Será desenvolvida adiante esta modalidade de assistência à alma. ${ }^{33}$ Finalmente, $14 \%$ dos testadores analisados nada indicou em relação a este assunto ou, ainda, que $4 \%$ deixou-o expressamente a critério dos testamenteiros e herdeiros. ${ }^{34}$ Podiam ser testadores de menos posses ou que confiavam tal aspeto ao bom senso dos testamenteiros e herdeiros. ${ }^{35}$ Uma questão, aliás, que é preciso elucidar, prende-se com os serviços religiosos prestados obrigatoriamente a qualquer defunto, pois muitos não faziam testamento. As constituições sinodais então em vigor apenas referiam que todos deviam ser sufragados conforme o costume do arcebispado, o que não ajuda a clarificar a dúvida. As constituições sinodais anteriores, de 1538, deixam entrever que todos os falecidos tinham direito a um ofício simples no momento do enterro, com a possibilidade da celebração prévia de uma missa de corpo presente. ${ }^{36}$ Ora, seriam alguns dos ofícios, mencionados pelos testadores bracarenses, correspondentes a este ofício de sepultura? E aqueles que não os solicitavam expressamente procediam deste modo por já estar subentendida a sua celebração?37

No entanto, o maior número de testadores era, ainda assim, aquele que pedia somente a celebração de missas de corpo presente ${ }^{38}$ durante o velório fúnebre. Estas missas podiam ser celebradas em vários templos e altares em simultâneo, tendo, no entanto, que decorrer durante o tempo de exposição do cadáver. Ao analisar os pedidos relativos às missas de corpo presente, excluindo as que, por vezes, os padres tinham de celebrar nas igrejas onde celebravam os ofícios, qual teria sido a evolução verificada ao longo do século XVIII? Haveria um aumento no número de sufrágios pedidos, ou teria sucedido a situação inversa?

Os testadores estudados solicitaram, maioritariamente, missas de corpo presente até um máximo de 30 sufrágios. ${ }^{39}$ De fato, cerca de $47 \%$ destes homens e mulheres pediram sufrágios dentro do referido quantitativo. É também de assinalar que, a partir de 1760, parece aumentar ligeiramente o número de indivíduos que determinava a celebração de um dia de "missas gerais". No total de testadores, cerca de $11 \%$ solicitaram essas missas, às quais alguns acrescentaram outros sufrágios devidamente quantificados. Devemos explicitar que a celebração das "missas gerais" não pressupunha um número fixo de sufrágios. Consistia em

33 Nas zonas rurais bracarenses, fora da cidade e seus arredores, ao invés, a celebração de ofícios foi bastante comum na Idade Moderna (Durães, 2000, p. 320-323).

34 Como sucedia cada vez mais em Múrcia, ao longo do século XVIII (Allemán Illán, 1988, p. 114-115).

35 Em 1707, as Constituições Sinodais da Bahia previam, para os pobres, a celebração de um ofício de três lições e de uma missa de corpo presente (Campos, 2000, p. 47).

36 Constituições Synodais do arcebispado de Braga. Lisboa: Oficina de Germão Galharde, 1538, fls. XLIII, XLVI e também as Constituiçõens Synodais do arcebispado de Braga ordenadas no anno de 1639 pelo illustríssimo Senhor Arcebispo D. Sebastião de Matos Noronha e mandadas imprimir a primeira vez pelo illustríssimo Senhor D. João de Sousa. Lisboa: Oficina de Miguel Fernandes, 1697, p. 445.

37 Na cidade do Porto, o ofício de corpo presente era obrigatório, mesmo para os pobres. Contudo, ao longo do século XVIII, o ofício de defuntos foi, progressivamente, sendo cada vez menos referido pelos testadores. Talvez estes não sentissem necessidade de mencionar algo que já era suposto (Rodrigues, 1991, p. 166, 170).

38 Mais uma vez é possível que, mesmo nestes casos, estivesse subentendida a celebração de um ofício no momento da sepultura dos defuntos, que os testadores não sentissem necessidade de mencionar expressamente.

39 Em Moguer, no início do século XVIII, a maioria dos testadores solicitou apenas uma ou duas missas cantadas de corpo presente (Lara Ródenas, 1988, p. 516). 
mandar celebrar o maior número possível de missas, durante um ou mais dias, conforme as possibilidades financeiras do testador, bem como o número de sacerdotes disponíveis e os locais de culto livres.

A estabilidade encontrada na evolução do número de sufrágios parece demonstrar que os bracarenses, ao longo da centúria, continuaram a conferir grande importância ao período do velório. Lembremos que, após a morte, a alma era sujeita a um juízo particular sobre o seu destino no além, podendo ser condenada ás penas infernais, ser logo aceite no Paraíso ou enviada para o Purgatório para ser purificada. Nesse julgamento efetuado por Deus, acreditavase na intercessão da Virgem Maria e dos santos, bem como no auxílio das preces dos vivos para que a alma do defunto não fosse condenada eternamente. Daí que fosse percebido como importante investir nos sufrágios celebrados no período de velório para conseguir este objetivo. ${ }^{40}$

Para muitos habitantes de Braga, o fim das exéquias fúnebres não significava o termo dos serviços religiosos que queriam celebrados pela sua alma. De fato, muitos indivíduos, $67 \%^{41}$ dos testadores analisados, solicitavam também a celebração de serviços pios pela sua alma após o enterro, com o objetivo de encurtar sua presença no Purgatório. Na maioria das vezes não era estipulado um prazo para essas celebrações, sendo apenas determinado que tivessem lugar o mais brevemente possivel.

A maior parte dos bracarenses estudados que determinou a celebração de serviços religiosos para depois do funeral decidiu que esse quantitativo se cifraria até 40 sufrágios. ${ }^{42}$ Assim, 36\% do total de testadores analisados determinou este quantitativo de missas, mas entre os indivíduos que solicitaram sufrágios para depois do enterro, verifica-se um aumento dessa percentagem para cerca de $54 \%$. Nota-se contudo uma tendência de, se no início do século eram poucos os que pediam menos de 20 missas, ao longo da centúria a situação se inverteu. Nas últimas décadas a maior parte dos testadores que solicitava até um máximo de 40 missas, concentrava-se no intervalo entre 1 a 20 sufrágios.

Os fiéis continuavam a pedir missas para depois do enterro, mas seu número tendeu a decrescer no fim do século. Seria este recuo ${ }^{43}$ reflexo de um crescimento na confiança da Providência Divina e na intercessão dos familiares? Ou traduziria as dificuldades financeiras de Portugal na segunda metade da centúria, quando as remessas de ouro brasileiro começaram a cair e também surgiram problemas econômicos da região de Braga, nas últimas décadas

40 Autores como Francisco Lorenzo Pinar (Lorenzo Pinar, 1991, p. 116) ou Máximo Garcia Fernández (Garcia Fernández, 1996, p. 89) concordam que a acumulação de missas solicitadas para o velório e exéquias fúnebres tinham como objetivo ajudar o defunto a evitar a condenação ao Inferno no juízo particular depois da morte.

41 Fonte: ADB, Testamentos do Fundo de Provedoria; AISB, Livro de testamentos da freguesia da Sé, 1738-1785, fls. 10-10v., 12-13, 19-19v., 26v-27v., 32-33, 35-36, 40v.-41, 50v.-51, 67v.-68, 74-75, 85-85v., 89-89v., 111v.112, 129-130., 134v.-135, 135, 147-148, 160-161, 165v.-166v., 175-176, 189, 197v.-198; Livro de testamentos da freguesia da Sé, 1785-1814, fls. 5-5v.,37v.-38, 49v.-50, 57v.-58.

42 Nas paróquias do concelho de Esposende, na Época Moderna, verificamos quantitativos de missas semelhantes (Faria, 2006, p. 799). Em Paris, os números chegaram a ser bem superiores. Em média, cada testador no século XVII pedia a celebração de 300 missas. Para este assunto confira-se (Croix, Alain e Roudaut, Fanch, 1984, p. 34).

43 Também em Sevilha se verificou um recuo no número de missas pedido por cada testador ao longo do século XVIII (Rivas Álvarez, 1986, p. 168). 
do século XVIII, quando foi palco de uma crise agrícola? É provável que ambos os fatores avançados se combinassem para explicar este cenário. ${ }^{44}$ Constata-se ainda que foram poucos os testadores que pediram "missas gerais" para depois do enterro, bem como a realização de ofícios. Estas modalidades, presentes no período de velório, eram quase inexistentes posteriormente. Sem o mesmo constrangimento temporal, os testadores preferiam apostar na celebração de um montante determinado de sufrágios, o instrumento por excelência de resgate das almas do Purgatório.

É igualmente pertinente verificar se os sufrágios estipulados pelos testadores, quer para o velório, quer a título posterior, tinham apenas por intenção o benefício espiritual dos mesmos, ou se, pelo contrário, sua perspectiva da salvação era mais global..45 Relativamente aos celebrados durante o período de velório, é notório que os testadores estavam quase exclusivamente preocupados com a salvação pessoal, apesar do número reduzido de quem pediu certos sufrágios em benefício de familiares defuntos, bem como em honra de santos que podiam servir como forma de requerimento para que agissem como intercessores pela sua alma junto de Deus, no momento do juízo individual após a morte. No que dizia respeito ao período decisivo do velório, em que se pensava que a alma seria julgada por Deus, era pertinente que os testadores concentrassem em si as intenções dos sufrágios que deixavam preceituados, conforme referido anteriormente.

A análise dos dados relativos às missas solicitadas para depois do enterro mostra uma situação diferenciada. De fato havia um leque variado de intenções. Não é possível negar que as missas prescritas em favor da alma do testador continuavam a ser as mais solicitadas. Uma percentagem de mais de $50 \%$ dos testadores analisados prescreveu estes sufrágios, embora na contagem dos que pediram sufrágios para depois do enterro essa percentagem se cifre em 75\%. Mas, no decurso do século XVIII constata-se que, à medida que diminui o número de testadores solicitadores de missas por intenção de si mesmos, cresceu, pelo contrário, o daqueles que estipulava missas com outras intenções. Assim, especificamente, verifica-se um aumento do número de indivíduos que prescreveu missas pelas almas de seus familiares. Se no início do século XVIII a grande maioria das missas solicitadas para depois do enterro tinham como objetivo somente a salvação da alma do testador do cárcere do Purgatório, em finais da mesma centúria constata-se que também era importante a libertação das almas de seus entes queridos (Lara Ródenas, 1994, p. 423). No cômputo geral da centúria, 29\% dos 250 testadores estudados solicitaram sufrágios com esta intenção, para depois do enterro. ${ }^{46}$

É de notar que não são apenas as missas solicitadas por alma dos familiares, aquelas que denotam um aumento de testadores a prescrevê-las. Também as missas pelas almas das

44 Em diversas regiões francesas a quebra no número de sufrágios solicitados teve lugar já na terceira década do século XVIII. Contudo a maior diminuição acontece a partir de 1760 (Vovelle, 1982, p. 260, 281). Nas regiões galegas de Tui e Santiago de Compostela, a diminuição começou a fazer-se sentir, ligeiramente, a partir de 1760 e de modo mais acentuado desde 1780 (González Lopo, 2002, p. 510-511).

45 No século XIV, na região da Flandres, existiam já exemplos de testadores que solicitavam missas de sufrágio pela alma dos seus familiares, para além da sua própria alma (Cohn Jr., 2000, p. 37).

46 Esta percentagem sobe para cerca $43 \%$ se considerarmos somente os testadores que solicitaram a celebração de missas no período de tempo posterior ao enterro. Segundo Michel Vovelle, nos fins do século XVIII, reforçouse a preocupação do reencontro dos defuntos com os seus familiares e amigos na ressurreição (Vovelle, 1983. p. 393). 
"obrigações" dos testadores (as almas por quem todo o cristão estava obrigado a rezar, o que incluiria igualmente as de familiares), bem como os sufrágios pelos confrades conheceram um aumento de referências, ainda que sejam poucos os casos. O leque de intenções alargou-se a amigos, conhecidos, benfeitores e, até, a todas as almas do Purgatório, embora em números mais modestos. Entre os familiares, as almas dos pais, irmãos e do cônjuge eram aquelas a quem os testadores dedicavam mais sufrágios. Num segundo plano surgiam os filhos, os tios e avós e até sogros e cunhados, sobretudo a partir de meados da centúria. Ao longo do século cresceu o número de missas solicitadas por familiares, como também as intenções pelos mesmos se diversificaram, conforme as cláusulas testamentárias bracarenses demonstram.

\section{Os legados pios perpétuos}

Se as missas e outros serviços fúnebres até aqui referidos eram celebrados de uma só vez, tendo como objetivo a salvação da alma no curto e médio prazo, é fundamental analisar as obrigações pias instituídas por alguns indivíduos, a título perpétuo. Estas obrigações eram os legados de missas perpétuas, através dos quais um legatário doava a uma instituição, a um indivíduo ou a um herdeiro familiar, certa quantia em dinheiro ou um conjunto de bens de raiz, como terras de produção agrícola ou casas de habitação, para sustentar a celebração de sufrágios perpétuos. Se o legado fosse entregue em dinheiro, era posteriormente emprestado pela instituição ou pelo indivíduo que o recebia, a particulares que pagariam todos os anos juros, até a devolução da quantia emprestada. Com esses juros, o recebedor do legado comprometia-se com o legatário a mandar celebrar missas ou outros serviços pios, por sua alma ou pelas de quem ele tivesse designado, a título perpétuo. ${ }^{47}$ No caso de o legado perpétuo ser instituído por meio de bens materiais, como terras ou casas, eram seus rendimentos que serviam para custear o pagamento dos serviços pios sufrágicos designados pelos legatários. ${ }^{48}$

As confrarias tiveram, na Época Moderna, um papel de destaque na instituição destes legados em favor da alma, recebendo várias doações, o que instigou o estudo deste fenômeno no meio confraternal bracarense setecentista..$^{49} \mathrm{O}$ estabelecimento de um legado pio perpétuo era feito de duas formas: mediante contrato celebrado entre o legatário e a instituição, ainda durante a vida do primeiro, que entraria em pleno vigor após sua morte, ou por uma doação testamentária, que a confraria podia recusar, se considerasse que as cláusulas do legado deixado em testamento lhe eram prejudiciais. A maioria dos legados analisados foi estabelecida por esta via, embora fosse também assinalável o número daqueles instituídos ainda durante a vida do legatário, demonstrando que certos fiéis procuravam assegurar ainda neste mundo um "seguro" para o além. Saliente-se que $77 \%$ dos legados estudados foram instituídos por membros do sexo masculino. Quantos sufrágios previam e com que periodicidade? E determinariam apenas

47 A esmagadora maioria dos legados analisados foi instituída por esta via.

48 A respeito das formas de fundação de legados pios perpétuos leia-se (Abreu, 1999b, p. 732-733) e ainda (Reis, 2003, p. 491-492).

49 As confrarias tiveram um papel de destaque na fundação de legados pios perpétuos (Reis, 2004, p. 215, 216). 
a celebração de missas ou contemplavam outras modalidades pias?50

O primeiro aspecto a assinalar está associado à importância que nestas irmandades teve a constituição de legados de missa cotidiana, ${ }^{51}$ ou seja, legados que prescreviam a celebração de uma missa todos os dias, segundo a intenção do instituidor. Esta instituição diária de celebração de uma missa era também designada como "capela." Deste modo, uma capela de missas impunha a celebração de uma missa diária.52 A celebração de uma missa cotidiana impunha a contratação de um capelão, encarregado exclusivamente de celebrar as missas desse legado. Tratava-se, assim, da modalidade mais abrangente na salvação da alma, implicando seu sufrágio diário. Na informação compulsada encontra-se um legado em que se estabeleceu a celebração de duas missas cotidianas, o que significou a contratação de dois capelães. O estudo dos legados cotidianos instituídos nestas confrarias evidenciou que dois instituidores determinaram a celebração no dia de Natal, de três missas em vez de uma, já que os clérigos estavam autorizados, nesse dia importante do calendário católico, a celebrar três sufrágios.

A seguir às missas cotidianas, as mais solicitadas foram as missas semanais, ${ }^{53}$ ou seja, fundações perpétuas que instituíam a celebração, todas as semanas, de uma ou mais missas, conforme a intenção do instituidor. Efetivamente, a maioria dos instituidores de missas semanais optou por determinar apenas uma única missa por semana. Todavia, constata-se a existência de indivíduos que solicitaram a celebração de duas a quatro missas semanalmente. Não tendo um cariz tão contínuo e abrangente como as missas cotidianas, os legados semanais não deixavam de ser também uma modalidade que mantinha regularmente presente o sufrágio das almas preceituadas pelos legatários. ${ }^{54} \mathrm{Em}$ qualquer dos casos, a preservação da memória dos defuntos no mundo dos vivos, para além de sua salvação, era igualmente um objetivo importante destes homens e mulheres que seria garantido de modo mais reforçado por esta periodicidade celebrativa. A celebração diária ou semanal dos sufrágios implicava uma constante e permanente lembrança das almas por quem eram celebrados. Desejava-se ficar na memória, para que os vivos intercedessem em favor de seus mortos, por meio de eucaristias, preces individuais e orações litúrgicas.

Outros legatários preferiram instituir certo número de missas avulsas, para serem celebradas ao longo do ano..$^{55}$ O número de sufrágios celebrados nesta situação era variável, todavia verifica-se que, na maioria dos casos, se encontravam num intervalo entre uma e 30 missas por ano. Salientam-se três legados de missas anuais superiores a 50 sufrágios, com 70 ,

50 Fonte: Livros de registo de todas as confrarias bracarenses em análise. Optamos por não discriminar os livros consultados devido ao seu elevado número.

51 Também na Misericórdia de Braga os legados de missas diárias e semanais alcançaram grande relevância no século XVIII (Castro, 2006, p. 532-536).

52 Para Laurinda Abreu (Abreu, 1999a, p. 108-111) e Ricardo Raimundo (Raimundo, 2007, p. 203) uma capela de missas correspondia essencialmente à celebração de uma missa diária. Contudo, autores como Maria Teresa Veloso afirmam que uma capela de missas podia implicar apenas a celebração de algumas missas por semana (Veloso, 1988, p. 14).

53 A irmandade de São Vicente no século XVIII destacou-se entre as suas congéneres, recebendo então muitos legados de missas quotidianas e semanais.

54 No ano de 1739, o padre barcelense Afonso de Magalhães e Barros determinou a celebração por sua alma de três missas semanais, acrescidas de uma missa em cada mês (Ferreira, 1990, p. 71-76).

55 A maioria das fundações pias setecentistas micaelenses pressupunha igualmente a celebração de um número reduzido de missas anuais (Costa, 2005, p. 318-319). 
107 e 132 missas respectivamente. O número total de missas celebradas era, nestes exemplos, superior ao dos legados que determinavam uma eucaristia semanal. Todavia, dentro da categoria das missas anuais, constituíram a exceção e não a regra.

Por outro lado, uma caraterística que distinguiu os legados de missas anuais instituídos nestas confrarias era o de, preferencialmente, estes sufrágios não terem dias determinados, limitando-se o instituidor a referir o volume de missas celebradas em cada ano. Existiram, contudo, algumas exceções. Houve quem declarasse pretender estabelecer a celebração de uma missa em dia de Fiéis Defuntos, mas também quem definisse a realização de oito sufrágios dentro do "oitavário" 56 do Natal. ${ }^{57}$ A escolha do dia de Fiéis Defuntos e da quadra natalícia era comum na Idade Moderna. Como já referido, no dia de Fiéis a Igreja recordava solenemente e pedia a Deus pelas almas dos que padeciam no Purgatório. Era, portanto, pertinente sua escolha como data de celebração de uma missa perpétua, por alma de um defunto. O Natal era uma época igualmente propícia para a celebração de sufrágios salvíficos, associando o nascimento de Jesus Salvador com o resgate das almas do Purgatório. Esta predileção pelo dia de Natal era patente através da instituição, por parte de vários legatários, de um legado que determinava a celebração de um "terno de missas" nesse dia. Ao longo de todo o século XVIII, constata-se que o pedido de missas perpétuas celebradas neste dia permanece. Alguns destes fiéis pediam "dois ternos de missas," reforçando a importância e a popularidade que esta modalidade de sufrágio das almas, no dia de Natal, desfrutava na Braga setecentista. ${ }^{58}$

A pesquisa verificou também que nem todos os legados de missa instituídos tinham como apenas como objetivo explícito a salvação das almas dos instituidores. Esta questão merece ser aprofundada: que intenções sufrágicas estavam presentes nos legados pios perpétuos instituídos, para além das almas dos instituidores? A análise permitiu constatar que os legados pios instituídos tinham dois destinatários principais: em primeiro lugar, o sufrágio das almas dos próprios instituidores e, em seguida, o das almas de seus familiares. Era em favor das almas destas duas categorias de indivíduos que os instituidores fundavam os legados pios perpétuos, os quais confiavam à administração das confrarias. A principal preocupação dos instituidores recaia sobre sua própria libertação do Purgatório mas, ao mesmo tempo, parece evidente que, para muitos destes homens e mulheres, essa libertação só faria sentido se fosse acompanhada pela salvação da alma de seus entes queridos, à semelhança do que verificava-se relativamente às intenções dos sufrágios não perpétuos. Nesse sentido, os legatários deixavam preceituada a determinação de sufragar e manter viva a memória, não só de si como, muitas vezes, também de seus familiares mais próximos. De certo modo, parece estar subjacente nestas disposições a vontade de reconstituição do contexto familiar no outro mundo.

Sendo a salvação individual e familiar a principal razão que movia os instituidores de legados pios perpétuos, a verdade é que não era a única. Deste modo, alguns legatários

56 Ao marcarem sufrágios para os "oitavários" de festas religiosas, os instituidores possibilitavam maior flexibilidade celebrativa às irmandades.

57 ARQUIVO DA IGREJA DE NOSSA SENHORA-A-BRANCA (doravante AINSB), Fundo da irmandade de Nossa Senhora-a-Branca, Livro de termos de mesa da confraria da Senhora-a-Branca, 1670-1741, fls. 52, 57; Livro de termos de mesa da confraria da Senhora-a-Branca, 1741-1766, fl. 70.

58 Certos testadores houve que, num mesmo legado solicitaram sufrágios para o dia de Natal, o de Todos os Santos e o de Fiéis Defuntos. Assim se confirma a importância destas datas na temática da salvação da alma em Braga no século XVIII (Pina, 1996, p. 129). 
lembraram-se das almas de seus amigos e benfeitores, tentando retribuir e pagar no além todos os benefícios e relações de amizade que tinham mantido com eles. Era uma maneira de mostrar sua gratidão com aqueles que, não pertencendo à sua família, tinham ajudado em algum momento, ou com quem tinham estabelecido relações de amizade. ${ }^{59}$ É neste sentido também que devem ser lidas as referências à celebração de sufrágios perpétuos, por alma de alguns indivíduos em particular, dos quais se desconhece o tipo de relações que mantinham com os instituidores. Possivelmente seriam pessoas amigas ou benfeitores próximos dos instituidores. Neste caso, além da preocupação com a salvação de sua alma, é possível o desejo de preservar na memória dos vivos a recordação de um amigo ou benfeitor em particular.

Houve igualmente legatários que incluíram nos seus legados pios o sufrágio das almas do Purgatório. Subjacente a estas intenções estava a preocupação com a libertação das almas de todos os crentes, cativas neste lugar, fundamentada na pregação clerical que reforçava a necessidade de se sufragar todas as almas padecentes, especialmente aquelas que não tinham ninguém que as invocasse junto de Deus. Esta inclusão de todas as almas padecentes nas intenções dos legados pios perpétuos era uma forma de o legatário viver com generosidade sua piedade religiosa, no que dizia respeito à salvação, facultando uma assistência espiritual às almas do outro mundo. Contudo, era possível que estes indivíduos tivessem ainda como objetivo, ao deixarem sufrágios pelas almas do Purgatório, obter o concurso destas para que, no momento da morte dos legatários, interviessem junto de Deus, para os livrar da condenação eterna. ${ }^{60}$

Alguns legatários instituíam missas perpétuas pelas almas "das suas obrigações e intenções" ou seja, por aqueles que tinham ou sentiam obrigação de sufragar (familiares, amigos, confrades...), ou por aquelas almas que só o instituidor conhecia, mas podia não querer divulgar. Houve outros que determinaram sufrágios perpétuos em honra de santos de sua devoção, como forma de celebração, mantendo viva a memória do legatário, mas também certamente com o objetivo de que os santos fossem seus intercessores junto de Deus.

Estes legados constituíam quase somente na celebração de sufrágios, embora com exemplos de legados que determinavam a existência de capelães no coro das igrejas rezando pelas almas dos legatários nas diversas horas canônicas do dia e, até, o exemplo de um legado que consistia tão somente no acender de velas no altar de um santo, no dia de sua festa. É de notar igualmente que, quando os legatários mandavam sufragar familiares e amigos num legado, geralmente reservavam certo número de sufrágios pela sua intenção em conjunto com outros sufrágios por alma do próprio legatário.

Para concluir esta questão, é importante avaliar o perfil social dos instituidores de legados analiados, embora em relação a cerca 25\% dos mesmos nada tenha sido apurado. $\mathrm{Na}$ instituição de legados pios perpétuos, ${ }^{61}$ assinala-se a importância dos membros do clero, pois $33 \%$ dos legados estabelecidos nas confrarias em estudo foram efetuados por religiosos,

59 É nas relações familiares e de amizade que o homem na Época Moderna manifesta o seu devir (Aymard, 1990, p. 459-461).

60 Pensamos que os legados pios perpétuos pelas almas do Purgatório eram os mais pertinentes, pois não deixariam sempre de haver almas desamparadas pelas quais ninguém se lembrava de pedir a Deus.

61 Na Santa Casa da Misericórdia de Guimarães o clero era igualmente o grupo social que instituiu maior número de legados, na Idade Moderna (Costa, 1999, p. 83). 
entre os quais cónegos, vigários e abades. A estrutura hierárquica da Igreja lembrava aos fiéis a importância da salvação das almas cativas do Purgatório, pela celebração dos serviços pios, dando o exemplo quando possuía meios para o fazer.

No que diz respeito aos outros instituidores, constata-se certa variedade em seu perfil. Alguns eram membros da fidalguia, militares de alta patente, bem como homens de letras e do direito. ${ }^{62}$ Outros eram homens de negócios ou indivíduos proprietários de terras e ricos "brasileiros" de torna-viagem, ${ }^{63}$ para além de fiéis que exerceram cargos importantes nas irmandades bracarenses. Entre as mulheres, algumas que, por seu vocativo de "dona," talvez pertencessem a famílias ricas ou fidalgas. Em geral, estes foram os indivíduos que estabeleceram os legados mais onerosos, como os das missas diárias e semanais.

Existiram ainda outros indivíduos fora destes grupos, que também aspiravam a sufragar eternamente, na medida de suas possibilidades, a salvação de sua alma ou as dos que lhes eram próximos. Embora correspondam a percentagens diminutas, alguns sapateiros, um carpinteiro, um ferreiro e um tamanqueiro, bem como até um antigo escravo que fora alforriado e se casara foram encontrados. Assim, também os indivíduos que exerciam ofícios mecânicos, que ganhavam seu sustento e pertenciam a grupos populares procediam à instituição destes mecanismos de salvação (Hanson, 1986, p. 67-70). É um sinal de que a preocupação com a salvação eterna da alma estava presente em todos os grupos sociais e que cada um tentava responder conforme suas possibilidades. ${ }^{64} \mathrm{O}$ receio de uma estadia prolongada nas penas do Purgatório era transversal aos diversos grupos da sociedade bracarense setecentista.

\section{Os locais de celebração: igrejas e altares}

As missas de sufrágio não perpétuo pela salvação das almas que os bracarenses deixavam prescritas no século XVIII eram celebradas na cidade, nas diversas igrejas paroquiais, confraternais, conventuais e até em capelas. Estes templos estavam equipados com mais de um altar, para além do altar-mor, para dar satisfação às necessidades celebrativas pelas almas do Purgatório. ${ }^{65}$ No estudo das missas deixadas em testamento pelos fiéis bracarenses, quer durante o velório quer para depois do enterro, ao longo de setecentos, pesquisamos se existiam igrejas, e sobretudo altares, a que os habitantes recorriam com maior frequência. ${ }^{66} \mathrm{Da}$ análise dos dados constatamos que os defuntos escolhiam frequentemente as igrejas de certas irmandades, como de São Vicente, Santa Cruz e Nossa Senhora-a-Branca, com o objetivo de nelas serem celebradas as missas por ocasião das cerimônias fúnebres. As igrejas paroquiais da cidade não eram tão procuradas para este fim, à exceção da igreja da Sé de Braga, a catedral

62 O investimento em missas perpétuas demonstrava não só a devoção religiosa de membros da nobreza e da burguesia, como também demonstrava o seu poder financeiro e económico (Araújo, 2001, p. 20).

63 Devido à exploração mineira, no século XVIII, foi constante o fluxo migratório de Portugal para o Brasil (Araújo, 2006, p. 31).

$64 \mathrm{Na}$ capital portuguesa grupos sociais como os lojistas, os lavradores ou os artífices estabeleceram vínculos perpétuos de apenas algumas missas anuais (Araújo, 1999, p. 437).

65 Tal como sucedia na igreja da Misericórdia de Vila do Conde, dotada de vários altares já no século XVII (Sem autor, 2010, p. 34-35, 212)

66 Era frequente os testadores indicarem os altares e igrejas onde desejavam que as suas missas fossem celebradas (Monteros Sánchez, 2005, p. 149, 159). 
da cidade. Menos significativa ainda parece ter sido a procura de sufrágios celebrados nos conventos das ordens religiosas, destacando-se apenas, neste caso, o convento do Carmo.

Os pedidos de missas celebrados em São Vicente eram sobretudo dirigidos para o altar desse santo que era privilegiado. Este fato ajuda também a explicar a razão desta escolha. Os sufrágios celebrados nos altares privilegiados tinham a vantagem de, em relação aos restantes, proporcionarem maior rapidez no resgate das Almas do Purgatório. ${ }^{67}$ Ora, o altar privilegiado desta igreja era detentor, já no século XVII, de muitas graças espirituais. Acreditava-se que cada celebrante de uma missa neste altar podia, com este ato, resgatar uma alma do Purgatório. ${ }^{68}$ Para além disso, é possível que os custos da celebração das missas fossem aí menores do que noutros altares congêneres, explicando este fato o sucesso deste altar. ${ }^{69}$

Contudo, os dados analisados demonstram ter sido o altar privilegiado de São Pedro de Rates da Sé Primaz aquele que foi mais solicitado pelos bracarenses setecentistas, no sentido de aí serem celebrados sufrágios por sua alma. Foi o arcebispo D. Frei Bartolomeu dos Mártires (1559-1581) que obteve esse estatuto junto do papa. A bula papal previa que qualquer missa aí celebrada podia libertar a alma sufragada que estivesse no Purgatório. Esta graça espiritual, aliada ao fato deste altar se situar no templo central da arquidiocese, poderá explicar o sucesso que conheceu em Braga, ao longo da Idade Moderna. Na verdade, muitos fiéis em Braga e na arquidiocese solicitaram sufrágios pela sua alma neste altar, entre os séculos XVI e XIX (Castro, 2001, p. 231-232 e 243). Na Sé de Braga tiveram ainda certa relevância as missas celebradas nos altares dos seus claustros e, em particular, no altar do Senhor da Agonia. Certamente que o fato de a Sé ser também o templo local com mais altares disponíveis para a celebração de missas fazia com que muitos bracarenses a escolhessem em seus testamentos, esperando deste modo obter maior rapidez na celebração dos sufrágios que deixavam prescritos pelas suas almas.

Estes eram, portanto, os locais de celebração preferidos pelos bracarenses em relação aos sufrágios celebrados até o momento do enterro, embora ainda assinale-se certa importância dos altares privilegiados da igreja da Misericórdia de Braga e da igreja da Ordem Terceira. ${ }^{70}$ Contudo, deve-se também referir que um número não desprezível de testadores não indicou locais de celebração de alguns destes serviços pios ou apenas referiu que estes podiam ter lugar "em qualquer altar", o que deixava esta decisão ao arbítrio dos testamenteiros. Os testadores teriam consciência das dificuldades dos testamenteiros em poder mandar celebrar os sufrágios em certos altares, já de si sobrecarregados com pedidos de missas e por isso, por vezes, concediam autonomia a este respeito.

67 Segundo Domingo González Lopo, os primeiros altares privilegiados surgiram no século IX, concedendo indulgência plenária pela alma de quem fossem celebradas as missas. Foi, contudo, no século XVII que se regulamentou de forma clara a sua concessão (González Lopo, 2002, p. 587).

68 AISVTE, Fundo da confraria das Almas de São Vicente, Livro de estatutos da irmandade das Almas de São Vicente, 1667, fls. 1-2. No fim do século XVI esta igreja de São Vicente recebeu as mesmas indulgências e graças espirituais da igreja de São João de Latrão em Roma, o que pode igualmente ajudar a explicar a importância desta igreja e do seu altar privilegiado (Costa, 1991, p. 15).

69 Os custos da celebração de missas por alma na igreja de São Vicente eram inferiores às de Santa Cruz. ARQUIVO DA IGREJA DEE SANTA CRUZ (doravante AISC), Fundo da irmandade de Santa Cruz, Livro de estatutos da irmandade de Santa Cruz, 1664, 1702, 1762, 1773, fl. 487v.; AISVTE, Fundo da irmandade de São Vicente, Livro dos estatutos reformados da irmandade de São Vicente, 1768, fl. 62v.

70 Sobre as Misericórdias e os altares privilegiados leia-se (Araújo, 2007, p. 384). 
Já no que dizia respeito às missas dos legados confraternais estas eram geralmente celebradas nos altares das igrejas dessas instituições como a igreja de São Vicente, a de Nossa Senhora-a-Branca, a de Santa Cruz ou a de Santa Ana ou, em alternativa, nas igrejas paroquiais onde estavam alocadas, como a igreja da Sé, da Cividade ou de São Vítor. Vale a pena sublinhar ainda a inexistência de diferenciação entre os sexos nas escolhas dos locais de celebração das missas de sufrágio, por ocasião da morte e após o enterro, a título perpétuo ou não. Homens e mulheres procuravam os mesmos altares, confiantes nas propriedades salvíficas que estes garantiam às suas almas no além.

\section{O pedido de indulgências}

As indulgências correspondiam ao perdão dos pecados dos fiéis e à diminuição das penas a que as suas almas estavam condenadas no Purgatório, devido aos pecados cometidos. ${ }^{71}$ Elas eram concedidas aos fiéis pelas autoridades eclesiásticas. O nosso estudo em particular centrou-se na atribuição de indulgências às confrarias bracarenses. Efetivamente tal concessão às organizações confraternais em geral tinha já alguns séculos de existência. ${ }^{72}$ As irmandades bracarenses procuraram munir-se destas regalias espirituais em favor dos seus membros, porém, para poderem beneficiar delas, os confrades tinham de cumprir certos requisitos. $O$ que se constatou foi uma certa uniformidade desses requisitos pios e rituais nas indulgências das diferentes instituições. Ao citarmos um exemplo é possivel fazer uma extrapolação. Os mesários da confraria do Santo Nome de Deus e São Gonçalo obtiveram um Breve de indulgências, concedido pelo papa Clemente XII, em 1739. Este documento determinava a concessão de indulgência plenária, o perdão e a remissão de todos os seus pecados, aos confrades que se tivessem confessado e comungado quando de sua entrada na confraria. ${ }^{73} \mathrm{Em}$ seguida, a mesma indulgência plenária era concedida a todos os confrades que, cumprindo os mesmos requisitos, invocassem o nome de Jesus no momento da sua própria morte. ${ }^{74}$ Portanto, de forma sintomática, a assistência espiritual da confraria às almas dos seus irmãos, através destes mecanismos espirituais, começava logo no momento do ingresso dos confrades, projetandose também no fim de suas vidas.

O Breve papal concedia a mesma indulgência plenária aos confrades que visitassem a capela e o altar onde estava situada a confraria, no dia da festa do seu santo. Uma vez aí presentes eram incitados a orar pela exaltação da Igreja Católica, a rezar pelo fim das heresias

71 As indulgências são o desconto temporal das penas a padecer no Purgatório, variando no número de anos perdoados (Froeschlé-Chopard, 1980, p. 202; Rodríguez Sánchez, 1994, p. 49).

72 Por exemplo, em 1536, o papa Paulo III concedera indulgências à confraria da Vera Cruz de Toledo (Recuenco Pérez, 2001, p. 9).

73 A indulgência plenária permitia a remissão de todos os pecados mortais confessados pelos fiéis. Por seu turno, a indulgência pleníssima remia todos os pecados veniais (aqueles menos graves) e a indulgência plenior remia todos os pecados em geral. Para além disso existiam também indulgências circunscritas a certo período de tempo, as quais eram de menor eficácia salvífica (Lorenzo Pinar, 1993, p. 479).

74 AISC, Fundo da irmandade do Santo Nome de Deus e São Gonçalo, Indulgencias perpétuas concedidas aos confrades e irmãos da venerável irmandade do Santíssimo Nome de Jesus, situada em a capela de São Gonçalo da freguesia de São Vítor extra muros desta cidade de Braga, pelo papa Clemente XII, 1739. 
existentes, pedindo a Deus a conversão dos hereges e dos infiéis, pela paz entre os príncipes cristãos e pela saúde do papa. O Breve concedia aos confrades uma indulgência de sete anos e "sete quarentenas" de perdão das penas do Purgatório, se orassem do modo acima mencionado, num dos restantes quatro dias festivos da confraria, à escolha dos mesários. Estas regalias espirituais podem ser entendidas como uma forma de apelar à participação nos momentos de exaltação festiva e religiosa da instituição, contribuindo para reforçar seu prestígio. ${ }^{75}$

Os irmãos da confraria do Santo Nome de Deus e São Gonçalo podiam igualmente alcançar 60 dias de perdão das penas no Purgatório, se executassem um conjunto de ações de caráter piedoso. ${ }^{76}$ Esta diminuição era-lhes garantida, em primeiro lugar, se assistissem, enquanto confrades, às missas e outros ofícios divinos celebrados na sua capela, o mesmo sucedendo em quaisquer ajuntamentos públicos ou "secretos"77 onde tomassem lugar, como, por exemplo, acompanhando as procissões da irmandade, bem como outras realizadas sob licença do Ordinário Diocesano. Para além destes atos pios, a atribuição dos referidos 60 dias de perdão era também possibilitada aos irmãos que acompanhassem os defuntos à sepultura, ou tomassem parte no cortejo que conduzia o Santíssimo Sacramento a casa de um enfermo. Em alternativa, não podendo fazer o acompanhamento do Santíssimo, a indulgência de 60 dias era-lhes facultada se ajoelhassem quando ouvissem o sino tocar, assinalando a saída do Santíssimo Sacramento da igreja e rezassem pelo enfermo um pai-nosso e uma salve-rainha. ${ }^{78}$ Para além disso, também a visita dos confrades aos doentes, com o objetivo de os consolar no sofrimento por que estavam a passar, era contemplada com esta indulgência. ${ }^{79}$ Os confrades eram convidados a se solidarizarem nos momentos de doença, sofrimento e morte de todas as pessoas em geral, numa relação que era mutuamente benéfica: os confrades deviam confortar os que sofriam, ajudando-os a preparar-se para a eventualidade da morte e alertando-os sobre a necessidade de cuidarem da salvação da sua alma, bem como acompanhar os defuntos à sepultura. Ao mesmo tempo, procedendo deste modo, recebiam o alívio de seus próprios castigos, no Purgatório. Ao contribuírem para a salvação dos outros, os irmãos da confraria contribuíam para sua própria salvação.

A indulgência que perdoava 60 dias de penas era igualmente facultada aos confrades que esclarecessem os indivíduos sobre os preceitos religiosos católicos e aos que tentassem corrigir quem os não seguia, de forma a colocá-los no caminho da salvação. As mesmas regalias espirituais eram atribuídas aos membros da instituição confraternal que fizessem as pazes com seus inimigos ou entre pessoas desavindas, bem como aos que rezassem cinco padre-nossos e cinco salve-rainhas pelas almas dos irmãos da irmandade ou que executassem qualquer obra de misericórdia espiritual e corporal. Ao instruírem as pessoas sobre os preceitos e comportamentos determinados pela Igreja, os confrades contribuíam para o controle e a

75 Ibdem.

76 Praticar a caridade, para além das orações e sufrágios, era essencial à salvação (Sá, 1998, p. 43).

77 Não sabemos de que reuniões se tratariam.

78 A Igreja recomendava aos fiéis que acompanhassem o Santíssimo Sacramento a casa dos enfermos como ato de piedade (Marques, 2000, p. 563).

79 AISC, Fundo da irmandade do Santo Nome de Deus e São Gonçalo, Indulgencias perpétuas concedidas aos confrades e irmãos da venerável irmandade do Santíssimo Nome de Jesus, situada em a capela de São Gonçalo da freguesia de São Vitor extra muros desta cidade de Braga, pelo papa Clemente XII, 1739. 
coesão sócio-religiosa, afastando a difusão de ideias que os pusessem em causa.

As condições preceituadas pela Igreja de Roma respeitantes à concessão de indulgências obtidas pela confraria do Santo Nome de Deus e São Gonçalo eram, grosso modo, aquelas que estavam previstas em relação às outras confrarias estudadas e que obtiveram estes benefícios espirituais no século XVIII.80 Todavia, não deixavam de existir algumas especificidades, como sucedia na confraria do Santíssimo Sacramento de São Vítor, em 1757. Para além das condições já mencionadas na confraria do Santo Nome de Deus e São Gonçalo, seus benefícios espirituais incluíam uma indulgência de 60 dias de perdão aos confrades que hospedassem pobres, bem como aos que rezassem cinco vezes a avé-maria e o pai-nosso, pelas almas dos colegas defuntos. ${ }^{81}$ De fato, o estudo comparativo dos benefícios espirituais concedidos às confrarias bracarenses revela que os procedimentos pios e caritativos dos confrades, tendo em vista a obtenção de indulgência divina, eram semelhantes aos da confraria do Santo Nome de Deus e São Gonçalo. Somente em relação aos dias festivos escolhidos pelas irmandades, nos quais os confrades podiam gozar destas graças, é que existiam variações. ${ }^{82}$

O estudo de tais instrumentos espirituais de salvação demonstra que, no século XVIII, eles mantinham sua importância na religiosidade bracarense. As confrarias procuravam munirse destes "tesouros da Igreja Católica" em favor de seus membros, de forma a cativar mais adesões às suas fileiras. As irmandades procuravam apetrechar-se destas regalias espirituais e as que já as possuíam no século XVIII, recordavam-nas em seus estatutos, procurando também sua atribuição a título perpétuo.

\section{Conclusão}

80 AISB, Fundo da confraria das Almas da Sé, Resumo das indulgências que concedeu o Santíssimo Padre Clemente XIV, ora presidente na lgreja de Deus, aos irmãos confrades da confraria das Almas da Santa Sé Primaz, 1772; Fundo da irmandade de São Crispim e São Crispiniano, Livro de estatutos da irmandade de São Crispim e São Crispiniano, 1702, fls. 6v.-8v.; Fundo da confraria de Nossa Senhora do Rosário da Sé Primaz, Indulgências da confraria de Nossa Senhora do Rosário, concedidas pelo papa Pio VI, 1796; Fundo da confraria de Santo Amaro da Sé, Breve de indulgências concedidas aos confrades de um e de outro sexo da confraria de Santo Amaro da Sé Primaz, 1752, não paginado; AISL, Fundo da confraria das Almas de São Lázaro, Edital de publicação de indulgências perpetuamente concedidas aos irmãos e irmãs da irmandade das almas sita na freguesia de São Lázaro pelo Papa Pio VI, 1789. AISV, Fundo da confraria do Santíssimo Sacramento de São Vítor, Estatutos da confraria do Santíssimo Sacramento da igreja de São Vitor, reformados em 1744, fls. 30-31v.; Tábua de indulgências da confraria do Santíssimo Sacramento de São Vitor, 1757; AISVTE, Fundo da confraria das Almas de São Vicente, Indulgências concedidas à confraria das Almas sita na capela de São Vicente desta cidade de Braga, pelo papa Clemente XIV, 1772.

81 AISV, Fundo da confraria do Santíssimo Sacramento de São Vítor, Estatutos da confraria do Santíssimo Sacramento da igreja de São Vitor, reformados em 1744, fls. 30-31v.; AISVTE, Fundo da confraria das Almas de São Vicente, Indulgências concedidas à confraria das Almas sita na capela de São Vicente desta cidade de Braga, pelo papa Clemente XIV, 1772; AISL, Fundo da confraria das Almas de São Lázaro, Edital de publicação de indulgências perpetuamente concedidas aos irmãos e irmãs da irmandade das almas sita na freguesia de São Lázaro pelo Papa Pio VI, 1789.

82 A confraria das Almas da Sé escolheu o dia da Natividade de Nossa Senhora (8 de setembro), o da Santíssima Trindade (no primeiro domingo depois do de Pentecostes), o de São João Baptista (24 de junho) e o do Arcanjo São Miguel (29 de setembro) para que neles os confrades pudessem obter sete anos e "sete quarentenas" de perdão de penas do Purgatório se visitassem a Sé de Braga e orassem nos termos que já referimos. AISB, Fundo da confraria das Almas da Sé, Resumo das indulgências que concedeu o Santíssimo Padre Clemente XIV, ora presidente na Igreja de Deus, aos irmãos confrades da confraria das Almas da Santa sé Primaz, 1772. Já a confraria de Santo Amaro da Sé determinou o dia de São Bartolomeu (24 de agosto), o dia de todos os santos (primeiro de novembro), bem as primeiras oitavas de Natal ou do Espírito Santo para que os seus irmãos beneficiassem das referidas indulgências de sete anos ou "sete quarentenas." AISB, Fundo da confraria de Santo Amaro da Sé, Breve de indulgências concedidas aos confrades de um e de outro sexo da confraria de Santo Amaro da Sé Primaz, 1752, não paginado. 
No século XVIII, a preocupação dos habitantes de Braga com sua salvação no além era um fato incontornável, refletido de diversas formas. Desde logo e em primeiro lugar, pela atenção que dedicavam, em seus testamentos, aos cuidados que pretendiam que fossem prestados às suas almas. Assim, os homens e as mulheres de Braga determinavam a celebração de missas e ofícios não perpétuos para evitar as penas infernais no juízo individual e, posteriormente, serem rapidamente resgatados do cativeiro do Purgatório. Efetivamente, a missa era considerada o principal meio de salvação: quantas mais fosse possível celebrar mais possibilidades tinha a alma de se salvar. E assim os bracarenses investiam nos sufrágios celebrados durante o velório, principalmente para se livrarem da condenação eterna, bem como naqueles que eram celebrados posteriormente para libertar suas almas do Purgatório.

Na temática da salvação, as confrarias locais desempenharam um papel relevante. Não só previam a celebração de missas pelos seus membros, como também se constituíram como importantes recebedoras de legados pios perpétuos, instituídos por indivíduos que, temerosos pela sua salvação, acreditavam ser fulcral investir em sufrágios perpétuos. Os mais ricos instituíam legados de missa diária ou semanal, enquanto os de menores posses se conformavam com a celebração de apenas algumas missas ao longo de cada ano. Cremos, contudo, que a preservação da memória do legatário entre os vivos era também, a par da salvação da alma, uma razão que os levava a apostar nesta modalidade perpétua celebrativa.

Nem todos tinham a possibilidade de investir em sua salvação. Quem se lembraria das almas mais desamparadas e esquecidas dos bracarenses setecentistas de então? Essa foi uma tarefa que tomaram a cargo as confrarias das Almas de Braga as quais, ao longo da centúria, procuraram celebrar de forma regular, contínua e periódica, missas em benefício de todas as almas cativas no Purgatório, um benefício espiritual para aqueles que, com poucas posses, não teriam sequer quem deles se lembrasse após a morte. Estas instituições cumpriam assim um sentido comunitário na salvação de todos.

\section{Referências bibliográficas}

ABREU, José Paulo. Em Braga de 1790 a 1805: D. Frei Caetano Brandão o reformador contestado. Braga: Universidade Católica Portuguesa; Cabido Metropolitano e Primacial de Braga, 1997. $383 p$.

ABREU, Laurinda. Memórias da Alma e do Corpo. A Misericórdia de Setúbal na Modernidade. Viseu: Palimage Editores, 1999a. 495p.

Uma outra visão do Purgatório: uma primeira abordagem aos breves de perdão e de redução. Revista Portuguesa de História. Coimbra, tomo XXXIII, p. 713-736, 1999b.

As comunidades litorâneas de Setúbal e Lisboa em tempos de Contra-Reforma. In: $O$ Litoral em Perspectiva Histórica (séc. XVI a XVIII). Porto: Instituto de História Moderna, p. 247258, 2002.

ALLEMÁN ILLÁN, Anastasio. Actitudes colectivas ante la muerte en Múrcia durante el siglo XVIII. 
Cadernos de História Moderna. Madrid, no 9, p. 95-120, 1988.

ARAÚJO, Ana Cristina. Vínculos de Eterna Memória: esgotamento e quebra de fundações perpétuas na cidade de Lisboa. In: Piedade Popular: sociabilidades, representações, espiritualidades. Actas do Colóquio Internacional. Lisboa: Terramar, p. 433-442, 1999.

Despedidas triunfais - celebração da morte e cultos de memória no século XVIII. In: JANCSÓ, István; KANTOR, Íris (org.). Festa. Cultura e Sociabilidade na América Portuguesa, vol. I. São Paulo: Imprensa Oficial, p. 17-33, 2001.

ARAÚJO, Maria Marta Lobo de. Balanços de vidas, medo da morte e esperança na salvação: os testamentos dos emigrantes portugueses para o Brasil (séculos XVII e XVIII. Cadernos de História. Belo Horizonte, vol. 8, no 9, p. 29-48, 2006.

As Misericórdias e a salvação da alma: as opções dos ricos e os serviços dos pobres em busca do Paraíso (séculos XVI-XVIII). In: FARIA, Ana Leal; BRAGA, Isabel Drumond (coord.). Problematizar a História. Estudos de História Moderna em homenagem em Maria do Rosário Themudo Barata. Lisboa: Caleidoscópio, p. 383-402, 2007.

ARIÉS, Philippe. O Homem perante a morte II - a morte asselvajada. Mem Martins: Publicações Europa América, 1988. 344p.

AYMARD, Maurice. Amizade e convivialidade. In: DUBY, Georges; ARIĖS, Philippe (org.). História da Vida Privada III: do Renascimento ao século das Luzes. Porto: Edições Afrontamento, p. 455-500, 1990.

BEIRANTE, Maria Ângela. As antigas confrarias da vila de Cabeção: espelho da sua vida social e religiosa. Cabeção: Edição do Autor, 2011. 116p.

CAMPOS, Adalgisa Arantes. A ideia do Barroco e os desígnios de uma nova mentalidade: a Misericórdia através dos sepultamentos pelo amor de Deus na paróquia do Pilar de Vila Rica (1712-1750). In ÁVILA, Afonso (dir.). O território do Barroco no século XXI. Ouro Preto: Roma Editora, p. 45-62, 2000.

CASTRO, Maria de Fátima. A irmandade e Santa Casa da Misericórdia de Braga. Braga: Santa Casa da Misericórdia de Braga e autora, 2001. 340p.

A Misericórdia de Braga. Assistência material e espiritual (Das origens a cerca de 1910), vol. III. Braga: Santa Casa da Misericórdia de Braga e autora, 2006. 678p.

COHN JR., Samuel K. The place of the dead in Flanders and Tuscany: towards a comparative history of the Black Death. In: GORDON, Bruce; MARSHALL, Peter. The place do the dead. Death and remembrance in Late Medieval and Early Modern Europe. Cambridge: Cambridge University Press, p. 17-43, 2000.

CONCEIÇÃO, Joaquim Fernandes da. Espiritualidade e Religiosidade no Portugal moderno O Agiologio lusitano do Padre Jorge Cardoso. Dissertação (Mestrado em História Moderna e Contemporânea). Programa de Pós-Graduação em Letras, Universidade do Porto: Porto, 1996. $208 p$.

COSTA, Américo Fernando da Silva. A Santa Casa da Misericórdia de Guimarães 1650-1800 (caridade e assistência no meio vimaranense dos séculos XVII e XVIII). Guimarães: Santa Casa da Misericórdia de Guimarães, 1999. 292p.

COSTA, Luís. A igreja paroquial de São Vicente. Braga, APPACDM, 1991. 70p. 
COSTA, Susana Goulart. Da eternidade à historicidade. Traços das fundações pias setecentistas na ilha de São Miguel. Arquipélago - História. Ponta Delgada, 2ª série, IX, p. 309-321, 2005.

CROIX, Alain; ROUDAUT, Fanch. Les bretons, la mort et Dieu, de 1600 à nos jour. Paris: Messidor/ Temps actuels, 1984. 264p.

DELUMEAU, Jean. Le péché et la peur. La culpabilisation en Occident XII.XVIII siécles. Paris: Fayard, 1989. 741p.

DURÃES, Margarida. Porque a morte é certa e a hora incerta... Alguns aspectos dos preparativos da morte e da salvação eterna entre os camponeses bracarenses (séculos XVIII-XIX). Sociedade e Cultura 2. Cadernos do Noroeste, Série Sociologia. Braga, vol. 13, (2), p. 296-335, 2000.

Enciclopedia de la Religion Católica, Tomo V. Barcelona: Dalmau y Jovier ediciones, 1953. $1584 \mathrm{p}$.

ENES, Maria Fernanda. As confrarias do Santíssimo e das Almas no âmbito da cultura barroca (um caso na diocese de Angra). In: Io Congresso Internacional do Barroco, Actas, Vol. I. Porto: Reitoria da Universidade do Porto e Governo Civil do Porto, p. 275-298, 1991.

ESTREIA, Nídia Maria Moura. As confrarias do cabido da Sé do Funchal. Funchal: Centro de estudos de História do Atlântico, 2002. 135p.

FARIA, Inês Martins de. A Igreja e o povo na vida e na morte séculos XVIII a XX (estudo com base em visitas pastorais e testamentos). In: NW, Noroeste. Revista de História, Congresso internacional de História Territórios, Culturas e Poderes, Actas, vol. I. Braga: Núcleo de Estudos Históricos da Universidade do Minho, p. 785-802, 2006.

FERREIRA, José. A confraria de Nossa Senhora de Monte de Fralães. Barcelos. Revista. Barcelos, $2^{\text {a }}$ série, $n=1$, p. 57-103, 1990.

FIGUEIREDO, Cecília Maria Fontes. O heterogéneo mundo dos esmoleiros e os mamposteiros da bula em Minas no século XVIII. Revista Nures. São Paulo, Ano VII, no 18, p. 39-54, 2011.

FROESCHLÉ-CHOPARD, Marie-Hélène. La religion Populaire en Provence Orientale aux XVIII siècle. Paris: Éditions Beauchesne, 1980. 420p.

GARCÍA FERNÁNDEZ, Máximo. Los castellanos y la muerte: religiosidad y comportamientos colectivos en el Antíguo Régimen. Valladolid: Junta de Castilla y Léon, 1996. 326p.

GONZÁLEZ LOPO, Domingo L. Los comportamientos religiosos en la Galicia del Barroco. Santiago de Compostela: Xunta de Galicia, 2002. 903p.

HANSON, Carl. Economia e Sociedade no Portugal Barroco 1668-1703. Lisboa: Publicações Dom Quixote, 1986. 332p.

LARA RÓDENAS, Manuel José. Epidemia, testamento e historia de las mentalidades. Morir de peste en la Juelva del siglo XVII. In: SERRANO MARTÍN, Eliseo (ed). Muerte, religiosidade y cultura popular. Siglos XIII-XVIII. Zaragoza: Instituto Fernandoel Católico, p. 393-432, 1994.

; GONZÀLEZ CRUZ, David. Piedad y vanidades en la ciudad de Moguer. Un modelo de mentalidad religiosidad religiosa y ritual funerario en el barroco de 1700 . Huelva en su historia. Huelva, vol. 2, p. 491-554, 1988.

LE GOFF, Jaques. O Nascimento do Purgatório. Lisboa: Editorial Estampa, 1993. 448p. 
LORENZO PINAR, Francisco Javier. Muerte y ritual en la Edad Moderna, el caso de Zamora (1500-1800). Salamanca: Ediciones Universidad de Salamanca, 1991. 311p.

MARQUES, João Francisco. Rituais e manifestações de culto. In: AZEVEDO, Carlos Moreira (dir.). História Religiosa de Portugal, vol. 2. Lisboa: Círculo de Leitores, p. 517-601, 2000.

MONTEROS SÁNCHEZ, Francisco Espinosa de los. La religiosidade popular gaditana a través de las disposiciones testamentárias del siglo XVI. Trocadero, Revista del Departamento de Historia Moderna, Contemporânea, de América y del Arte. Cadiz, (17) p. 147-162, 2005.

PINA, Isabel Castro. Ritos e imaginário da morte em testamentos dos séculos XIV e XV. In: MATTOSO, José (dir). O reino dos mortos na Idade Média peninsular. Lisboa: Edições João Sá da Costa, p. 125-164, 1996.

RAIMUNDO, Ricardo Varela. Morte vivida e economia da salvação em Torres Novas (16701790). Torres Novas: Município de Torres Novas, 2007. 423p.

RECUENCO PÉREZ, Julián. Religiosidad popular en Cuenca durante la Edad Moderna: el origen de las cofradías penitenciales de semana santa. Hispania Sacra. Madrid, vol. 53, no- 107, p. 7-30, 2001.

REIS, João José. A morte é uma festa: ritos fúnebres e revolta popular no Brasil do século XIX. São Paulo: Companhia das Letras, 2004. 360p.

REIS, Maria de Fátima dos. A Misericórdia de Santarém: estruturação e gestão de um património. Cadernos do Noroeste. Série História. Braga, no 3, vol. 20 (1-2), p. 485-496, 2003.

RIVAS ÁLAVAREZ, José António. Miedo y piedad: testamentos sevillanos del siglo XVIII. Sevilha: Diputación Provincial de Sevilla, 1986. 263p.

RODRIGUES, Maria Manuela. Morrer no Porto durante a época barroca: atitudes e sentimento religioso. Dissertação (Mestrado em História) Programa de Pós-Graduação em Letras. Universidade do Porto: Porto, 1991. 271p.

RODRIGUÉZ SÁNCHEZ, Ângel. La muerte en España: del miedo a la resignación. In: SERRANO MARTIN, Eliseo (ed.). Muerte, Religiosidad y Cultura Popular. Siglos XIII-XVIII. Zaragoza: Instituto "Fernando el Católico", p. 35-51, 1994.

SÁ, Isabel dos Guimarães. Práticas de caridade e salvação da alma nas Misericórdias metropolitanas e ultramarinas: séculos XVI-XVIII: algumas metáforas. Oceanos. Lisboa, 35, p. 42-50, Jul.-Set. 1998.

SANTA CASA DA MISERICÓRDIA DE VILA DO CONDE. Um legado. 1510-1975, vol. I. Vila do Conde: Santa Casa da Misericórdia de Vila do Conde, 2010. 627p.

SOLÉ, Maria Glória Santos. Meadela, comunidade rural do Alto Minho, sociedade e demografia: 1593-1850. Guimarães: Núcleo de Estudos da População e Sociedade da Universidade do Minho, 2001. 386p.

VELOSO, Maria Teresa Nobre. A morte nos testamentos dos clérigos bracarenses do século XIII. Coimbra: Faculdade de Letras da Universidade de Coimbra, 1988. 41p.

VOVELLE, Michel. Mourir autrefois attitudes collectives devant la mort aux XVII et XVIII siècles. Paris : Gallimard, 1974. 250p.

Idéologies et Mentalités. Paris: Maspéro, 1982. 331p. 
La mort et l' occident de 1300 à nos jours. Paris: Éditions Gallimard, 1983. 793p.

Recebido em: 06 de setembro de 2016

Aprovado em: 31 de outubro de 2016 